\title{
Agronomical and quality differences of four fig cultivars grown in Brazil
}

\section{Diferenças agronômicas e qualidade de quatro cultivares de figo cultivados no Brasil}

\author{
Rafael Augusto Ferraz'; Sarita Leonel2*; Jackson Mirellys Azevêdo Souza3; \\ Joyce Helena Modesto ${ }^{3}$; Rafael Bibiano Ferreira ${ }^{3}$; Marcelo de Souza Silva ${ }^{3}$
}

\section{Highlights}

The possible varietal diversification can be indicated for fig growers.

'Roxo de Valinhos' and 'PI-189' fruits have higher antioxidant activity.

Anthocyanins is the predominant pigment in 'PI-189' and 'Roxo de Valinhos'.

In 'Troyano' fruits, the main pigment is carotenoids.

The PCA highlights the differences between cultivars, especially PI-189.

\begin{abstract}
Figs consumption date back to the beginnings of civilization. Currently, consumers have become more demanding about quality of fruits, and figs are then highly indicated, since it is rich in nutrients, making them a great addition to a healthy diet. Although there is only one commercial fig cultivar that is commonly grown in Brazil, different cultivars should be considered for the diversification of fig production with regards to their yield and fruit quality. This research aimed at evaluating growth, yield, physicochemical characteristics and bioactive compounds of figs grown in Brazil. Then, four cultivars (Roxo de Valinhos, White Genova, PI189 and Troyano) were studied to determine canopy volume, productive efficiency, soluble solids - SS, $\mathrm{pH}$, titratable acidity - TA, SS/TA ratio, sugars, ascorbic acid, phenolic compounds, pigments and antioxidant activity. The cv. White Genova presented the highest canopy volume, while 'Roxo de Valinhos', 'PI-189' and 'Troyano' performed the greatest productive efficiency. The cvs. Roxo de Valinhos, White Genova and Troyano produced fruits with higher content of SS, reducing sugars and SS/TA ratio, while the fruits of 'PI189' and 'Roxo de Valinhos' contained the highest levels of antioxidant activity. PCA enabled to differentiate the studied cultivars, which evidenced that PI-189 was the most different of all.
\end{abstract}

Key words: Antioxidants. Ficus carica L. Phenolic compounds. Tree performance. Yield.

1 Prof., Amazonas Federal Institute, IFAM, Itacoatiara, AM, Brazil. E-mail: rafael.ferraz@ifam.edu.br

2 Full Prof., School of Agriculture, São Paulo State University, UNESP, FCA, Botucatu, SP, Brazil. E-mail: sarita.leonel@ unesp.br

${ }^{3}$ Graduate Students of The Agronomy/Horticulture Graduate Program, UNESP, FCA, Botucatu, SP, Brazil. E-mail: jackson.mirellys@hotmail.com; joyce_helena_modesto@hotmail.com; aprigio_bibiano@hotmail.com; mace-losouza@hotmail.com

* Author for correspondence

Received: July 25, 2020 - Approved: Sept. 02, 2020 


\section{Resumo}

O consumo de figos remonta ao início da civilização. Nos dias atuais os consumidores se tornam cada vez mais exigentes com a qualidade das frutas, neste cenário, os figos são altamente indicados, pois são ricos em nutrients e um ótimo complemento para uma dieta saudável. Embora exista apenas uma cultivar comercial de figo comumente cultivada no Brasil, diferentes cultivares devem ser consideradas para a diversificação da produção com base no rendimento produtivo e qualidade dos frutos. Portanto, este estudo teve como objetivo avaliar a eficiência produtiva, as características químicas e os compostos bioativos de figos cultivados no Brasil. Para isso, quatro cultivares (Roxo de Valinhos, White Genova, PI-189 e Troyano) foram avaliadas quanto ao volume de copa, eficiência produtiva, sólidos solúveis - SS, pH, acidez titulável AT, relação SS/AT, açúcares, ácido ascórbico, compostos fenólicos, pigmentos e atividade antioxidante. A partir dos resultados, verifica-se que 'White Genova' apresentou o maior volume de copa, enquanto 'Roxo de Valinhos', 'Pl-189' e 'Troyano' apresentaram a maior eficiência produtiva. Foi possível verificar também que 'Roxo de Valinhos', 'White Genova' e 'Troyano' produziram frutos com maior teor de SS, açúcares redutores e maior relação SS/AT, enquanto os frutos de 'PI-189' e 'Roxo de Valinhos' continham níveis mais altos de atividade antioxidante. Por meio da PCA evidenciou-se que a PI-189 é a mais distinta dentre as cultivares avaliadas.

Palavras-chave: Antioxidantes. Ficus carica L. Compostos fenólicos. Desempenho produtivo. Produtividade.

\section{Introduction}

Figs have been grown since ancient time; they are therefore considered sacred in some cultures. Moreover, current researches have already evidenced the health benefits of figs (Palmeira et al., 2019), and Brazil has been lately considered one of the major producers of fig (Ficus carica L.) in the world, as it ranked eleventh with 23.7 thousand tons in 2018 (Food and Agriculture Organization [FAO], 2020).

There is a great genetic diversity within fig cultivars, provided that hundreds of them have been globally described. Such diversity enables to expand the commercialization of the fruits, whose ripening times vary according to cultivars and environmental conditions (Khadivi, Anjam, \& Anjam, 2018).

There is plenty of 'Roxo de Valinhos' production in the state of São Paulo, their trees are robust and highly productive, well adapted to weather changes and resistant to drastic winter pruning in Brazil. The fruits of 'Roxo de Valinhos' are large, elongated pyriform with short peduncle, but are extremely perishable, especially the ripe ones. 'Roxo de Valinhos' has therefore a short shelf-life (Rodrigues, Correa, \& Boliani, 2009), and thereafter the introduction of new cultivars is highly needed to diversify the fig production in Brazil.

Some collections of fig cultivars are kept by scientific institutes and universities for research purpose, such as 'White Genova', 'Troyano' and 'Pl-189'. Fig orchards in Brazil can be diversified, but cultivars must be evaluated at first. 'Troyano' and 'White Genova' are italian fig cultivars that produce parthenocarpy fruits. 'White Genova' fig produces a decent breba crop, with fruits weighing about $80 \mathrm{~g}$, the pulp texture is gelatinous and presents a mild flavour but is highly susceptible to deterioration. 'Troyano' fig is widely grown in the United 
States, where production is concentrated in late summer (breba figs) and early autumn (mammoni figs) (Khadivi et al., 2018). At last, PI189 is a mutant selection, formed by cuttings from 'Roxo de Valinhos' buds irradiated with gamma ray, PI-189 produces good yields, and has a small closed ostiole (Rodrigues et al., 2009).

The diversification in fig production are more likely to have positive outcomes, such as well adapted crops, consumer market proximity and export possibilities of fresh fruits, since will bring a good variety for producers and consumers.

Therefore, new cultivars are extremely promising in Brazil, as figs can be commercialized in many ways, that is, ripe figs are destined for the fresh fruit market, while the half-ripe ones are destined to fruit industry to produce jams and canned figs. The productive performance is not the only aspect to be considered, but also the quality of fruit in terms of bioactive compounds, since many consumers are searching for functional foods.

Figs are an important source of minerals (i.e. calcium) and vitamins (i.e. thiamine and riboflavin), in addition to high content of amino acids, fibres and bioactive compounds (mainly phenolic acids, flavonoids and carotenoids) (Arvaniti, Samaras, Gatidou, Thomaidis, \& Stasinakis, 2019).

Besides the difference among cultivars, varieties and species, the biosynthesis and accumulation of bioactive compounds also depends on management practice, weather changes, ripening stages and storage conditions, provided that the phenolic profile of figs depends on the cultivar, according to Vallejo, Marín and Tomás-Barberán (2012), who evaluated 18 spanish fig cultivars and found lower total phenol content in green figs when compared to dark fig cultivars. Similarly, Veberic, Colaric and Stampar (2008) also found a wide diversity of phenolic acids and flavonoids of fig trees in the Mediterranean. Regardless of cultivar, figs are relevant dietary source of phenolic compounds, the consumption of fruits, which are rich in phenolic compounds and antioxidant activity, act as a "barrier" against cancer, according to Corrêa et al. (2018).

The fig orchards in Brazil is practically based on only one cultivar, Roxo de Valinhos, which although present many favorable characteristics, has in short shelf life its bigger restriction. Therefore, the introduction of new genotypes that agree growers and consumers is urgent and necessary.

Considering that there is a lack of literature about the productive performance and postharvest quality of different fig cultivars grown in Brazil, and that such studies represent the basis for selecting, diversifying and recommending fig cultivars that shows great productive performance and high quality of fruits, the goal of present study was to evaluate the agronomical and fruit quality differences of four fig cultivars with diversification potential for growing in Brazil.

\section{Experimental area characterization}

The experiment was carried out at the São Manuel Experimental Farm of the School of Agriculture (UNESP, FCA) located at $22^{\circ} 51^{\prime} 55^{\prime \prime} \mathrm{S}, 48^{\circ} 26^{\prime} 22^{\prime \prime} \mathrm{W}$ at an altitude of 810 $\mathrm{m}$ a.s.l. According to the Köeppen-Geiger, the climate of the area is classified as Cwa, that is, humid subtropical climate (mesothermic), with 
concentrated rains from November to April (summer) and an average annual rainfall of $1433 \mathrm{~mm}$; the mean temperature of the hottest month exceeds $19.3{ }^{\circ} \mathrm{C}$ (Cunha \& Martins, 2009).

\section{Plant material}

The fig trees were two and three years old and were planted at $3 \mathrm{~m}$ spacing between rows and $2 \mathrm{~m}$ between plants. The trees were managed according with the recommendations for fig orchards, being submitted to winter pruning in July month, in both crops seasons evaluated. After pruning, six branches were conducted per tree.
The fruits were harvest at commercial maturity stage with skin is visually colored violet brown green and when the fruit flesh gave slightly when touched (Crisosto, Bremer, Ferguson, \& Crisosto, 2010).

In this study, four cultivars were evaluated, as follows: 'PI-189', fig mutant selection of 'Roxo de Valinhos' (Figure 1A); 'Roxo de Valinhos' was used as a control, as producers know well (Figure 1B); 'Troyano' and 'White Genova', the Germplasm Bank of Campinas Agronomic Institute (IAC) selected these Italian cultivars that were both kept in the Germplasm Bank of School of Engineering (FEIS - UNESP) in the city of Ilha Solteira, state of Sao Paulo (Figures 1C and 1D).
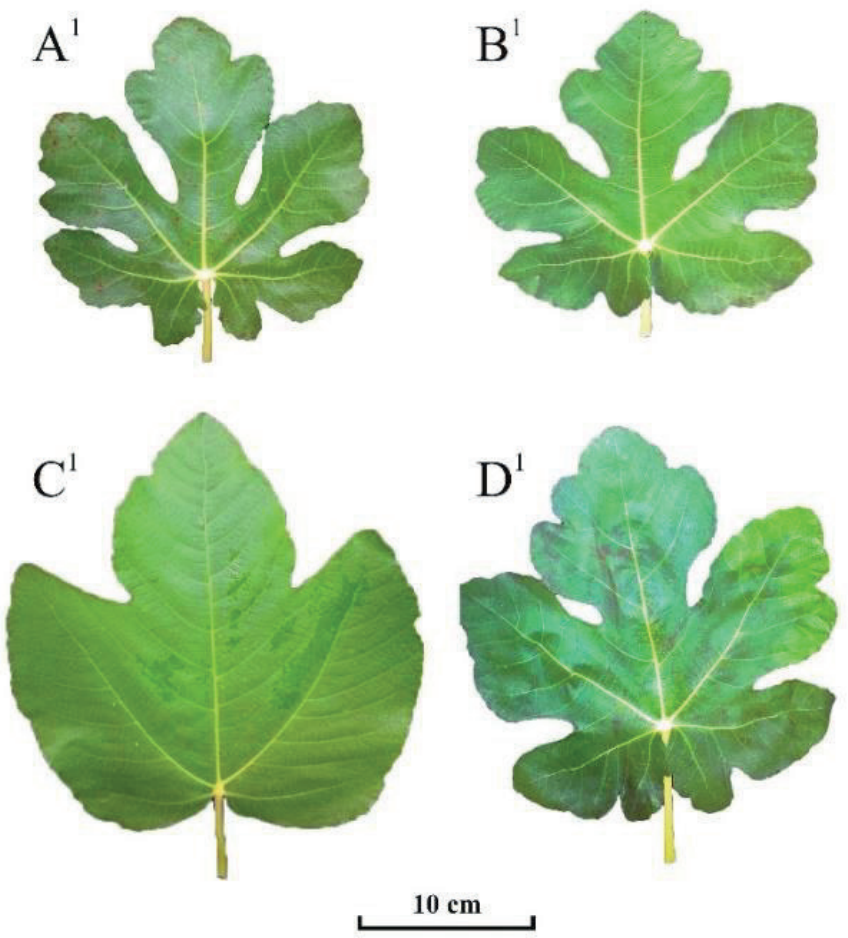
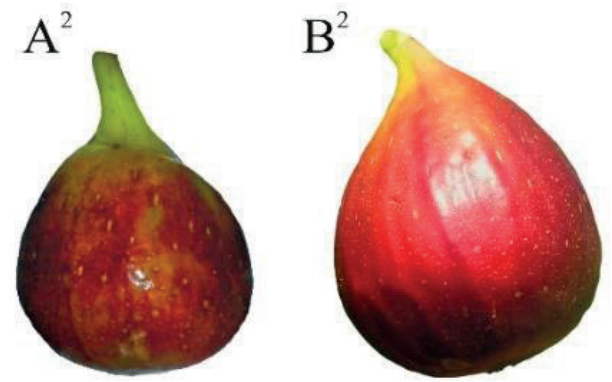

$\mathrm{C}^{2}$

$\mathrm{D}^{2}$
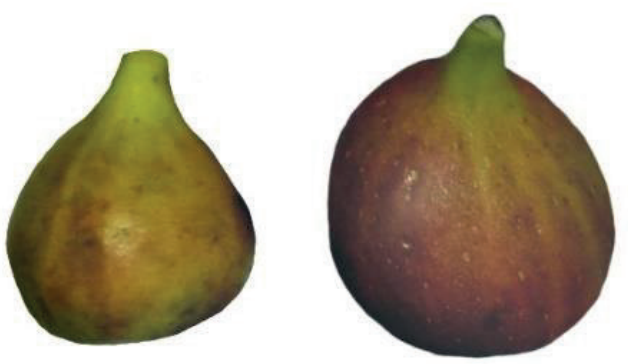

$1 \mathrm{~cm}$

Figure 1. General aspect of leaves and fruit fig cultivars PI-189 (A), Roxo de Valinhos (B), Troyano (C) and White Genova (D) grown in Botucatu, São Paulo State, Brazil. 


\section{Canopy volume and productive efficiency}

Canopy volume (V) was measured by considering canopy radius $(\mathrm{R})$ and height $(\mathrm{H})$ with a $2 \mathrm{~m}$ graduated ruler, to estimate canopy volume the following formula was used $V=2 / 3$ $\pi \mathrm{R}^{2} \mathrm{H}$, with the results expressed in $\mathrm{m}^{3}$ (Mendel, 1956). Productive efficiency was calculated through the ratio between production per plant (g) and canopy volume $\left(\mathrm{m}^{3}\right)$, with the results expressed in $\mathrm{g} \mathrm{m}^{-3}$.

\section{Chemical characteristics of fig fruits}

The extracts were homogeneously prepared from whole fruit by using a hand mixer (model RI1364, Philips Walita Viva Collection). All samples from each plot were submitted to the extraction procedure.

Soluble solids (SS) were determined with a digital refractometer (Atago 3405 PR-32A Palette-Style) by using $1 \mathrm{~g}$ sample of fig extract, with the results expressed as degrees Brix. Titratable acidity (TA) was obtained on titration with sodium hydroxide $(0.1 \mathrm{~N})$ in a solution containing $1 \mathrm{~g}$ sample of fig extract, $50 \mathrm{ml}$ of distilled water and $0.3 \mathrm{ml}$ of phenolphthalein (Instituto Adolfo Lutz [IAL], 2008), with the results expressed as a percentage of citric acid. Then, the indices of maturation were obtained through the relationship between SS and TA.

The reducing (glucose + fructose), nonreducing (sucrose) and total soluble sugars followed the Nelson method (1944). Therefore, $1 \mathrm{~g}$ sample of fig extract diluted in $100 \mathrm{ml}$ of distilled water. The evaluations were performed using a UV-Vis spectrophotometer (BEL Photonics ${ }^{\oplus}$, Brazil) in wavelength at $535 \mathrm{~nm}$, with the results expressed as percentage (\%).

\section{Bioactive compounds}

The fresh fruits were cut into small slices, frozen in liquid nitrogen and macerated with mortar and pistil in the presence of liquid nitrogen to determine the bioactive compounds. Except for the contents of ascorbic acid, as a sample of homogenised fig extract was used to assess the chemical characteristics.

The ascorbic acid content followed the methods 967.21 according to the Association of Official Analytic Chemists [AOAC] (1995). Therefore, $10 \mathrm{~g}$ sample of homogenised fig extract is suspended in $100 \mathrm{~mL}$ dilute solution of $3 \%$ metaphosphoric acid. Subsequently, this volume was filtered, and $5 \mathrm{~mL}$ was then titrated with 2,6-Dichlorophenolindophenol (DCPIP). The standard curve was obtained by titrating a solution containing a known amount of ascorbic acid, with the results expressed in terms of $\mathrm{mg}$ per $100 \mathrm{~g}$.

The use of 2,2-Diphenyl-1picrylhydrazyl assay (DPPH, Sigma-Aldrich Brazil) enabled to determine the antioxidant activity, according to methods of BrandWillians, Cuvelier and Berset (1995). Then, $250 \mathrm{mg}$ sample were used, where extract was obtained from pure methanol. Subsequently, the absorbance was measured at $517 \mathrm{~nm}$ using a UV-Vis spectrophotometer (BEL Photonics ${ }^{\circledR}$, Brazil). The percentage of DPPH inhibition was therefore calculated fromabsorbance readings. These values were used in an adjustable Trolox calibration curve, with the results expressed in terms of Trolox equivalent antioxidant capacity (TEAC) for extract $\left(\mathrm{mg} 100 \mathrm{~g} \mathrm{~g}^{-1}\right)$.

The total phenolic compounds of fresh fig fruits were determined by the colorimetric methods with Folin-Ciocalteau reagent (Swain 
\& Hills, 1959). Then, $250 \mathrm{mg}$ sample were used, where extract was obtained from pure methanol. Subsequently, the absorbance was measured at $725 \mathrm{~nm}$ using a UV-Vis spectrophotometer (BEL Photonics ${ }^{\circledR}$, Brazil); and compared to a calibration curve obtained for gallic acid, with the results in terms of $\mathrm{mg}$ $100^{-1}$ in gallic acid equivalent (GAE).

Total flavonoids were extracted from $70 \%$ acidified methanol, measuring absorbance at $425 \mathrm{~nm}$ in a spectrophotometer, with the results expressed in terms of mg rutin equivalent per $100 \mathrm{~g}$ fresh weight (Popova et al., 2004).

For total pigments, it was used acetone solution (Phosphate buffer, Tris- $\mathrm{HCl}[7.2 \mathrm{pH}$, in $80 \% \mathrm{EtOH}$ ), the readings were then made in spectrophotometer at $663 \mathrm{~nm}$ (chlorophyll a), at $647 \mathrm{~nm}$ (chlorophyll b), at $537 \mathrm{~nm}$ (anthocyanin) and at $470 \mathrm{~nm}$ (carotenoids) (Sims \& Gamon, 2002). Total chlorophyll content is exactly the sum of chlorophylls A and B. All procedures were conducted in a dark environment, with the results expressed in terms of ug $100 \mathrm{~g}^{-1}$.

\section{Statistical analysis}

The experiment was conducted in field. The randomized complete block design arranged in $4 \times 2$ factorial arrangement was used to assess the data. The first factor is related to cultivars and the second one to the evaluated seasons (2014/2015 and 2015/2016). Four blocks (cultivars) were therefore set up with six trees per treatment and five replicates, totaling 30 trees per cultivar. The variables canopy volume and productive efficiency were analyzed in both seasons. But the peel and pulp of twenty fruits were used for the analysis of physicochemical and bioactive compounds in the season of 2015/2016.

Normality was checked using the Shapiro-Wilk test. Analysis of variance (F test) was used to determine the significance level between factors at 1 and $5 \%$ probability. When significant, data were submitted to Tukey's test for means comparison ( $p \leq 0.05$ ).

\section{Results and Discussion}

\section{Canopy volume and productive efficiency}

There was no interaction effect of cultivars and seasons on canopy volume and productive efficiency. However, cultivars individually affected the mentioned characteristics $(p<0.01)$, while the seasons individually affected canopy volume $(p<0.01)$.

'Troyano' (3.19 m³) and 'White Genova' $\left(2.69 \mathrm{~m}^{3}\right)$ showed the highest canopy volume in both seasons, while the lowest vegetative development was found in 'PI-189' (0.82 $\mathrm{m}^{3}$ ) (Figure 2A). Nevertheless, the greatest productive efficiency was conferred to 'PI-189', 'Roxo de Valinhos' and 'Troyano' (Figure 2B). According to Cantuaria-Avilés, Mourão, Stuchi, Silva and Nunez (2010), there is a negative correlation to some extent between productive efficiency and canopy volume. The results found in 'PI-189', 'White Genova' and 'Roxo de Valinhos' corroborate these observations. On the contrary, the highest canopy volume found in 'Troyano', did not affect production. 

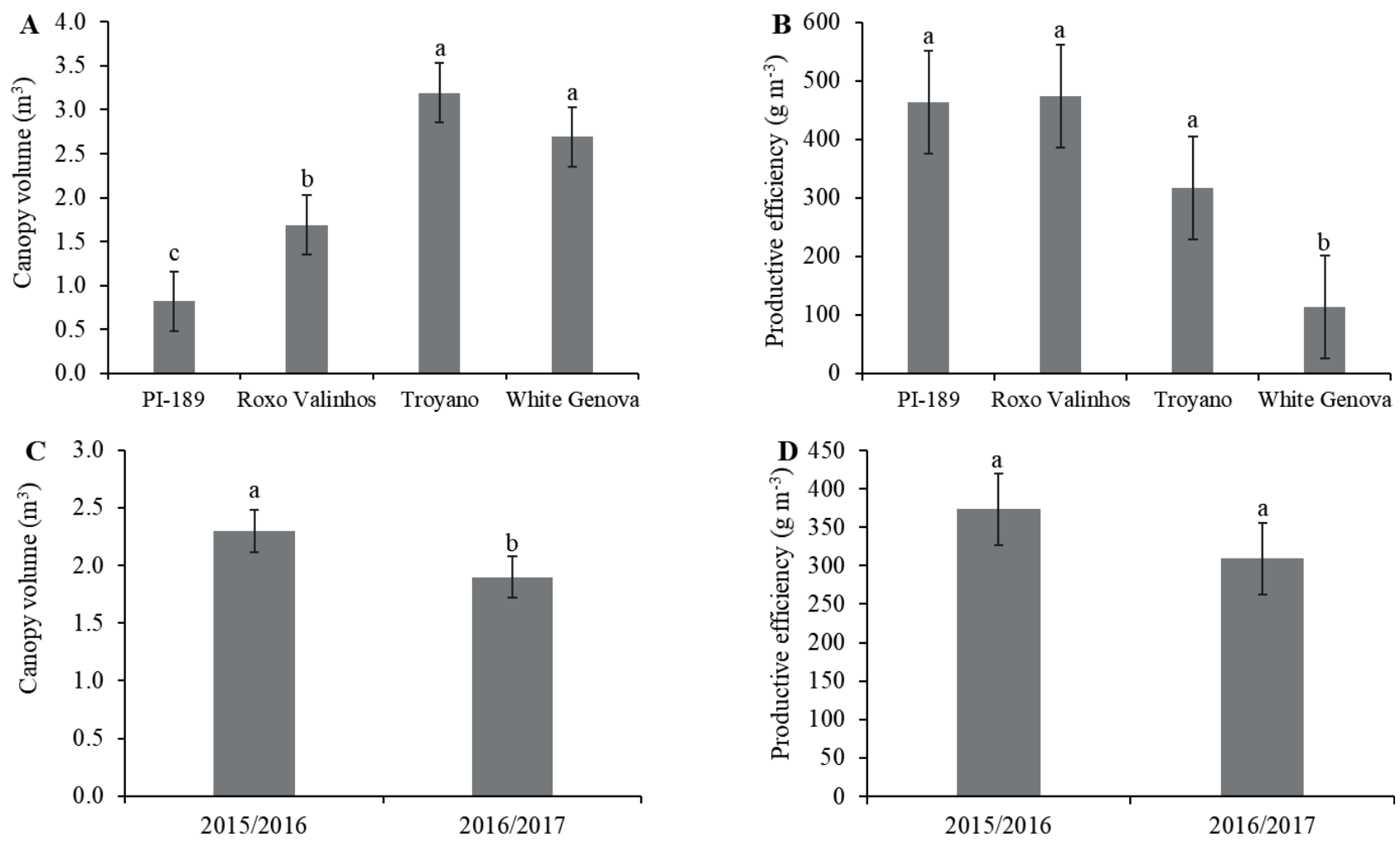

Figure 2. Canopy volume $(A)$ and productive efficiency $(C)$ of four fig fruit cultivars and the effect of two seasons on these variables $(B, D)$.

Means followed by the same letter each column do not differ statistically from each other by Tukey's test $(p<0.05)$. The bars represent the standard deviations for each column $(n=4)$.

High productive efficiency and low vigor are important characteristics when higher populations are tested for production systems. The results obtained show that 'Roxo de Valinhos' and 'PI-189' were well adapted to high density systems by pruning back hard every year in winter. The great vegetative vigor observed in 'Troyano' and 'White Genova' emphasizes the need for continuous follow up examinations of these cultivars at different planting densities.

Rodrigues et al. (2019a) considered moderated vegetative growth in 'Roxo de Valinhos', 'White Genova' and 'Troyano', while
'PI-189' exhibited the lowest growth of all. Such studies will support producers to select the most promising cultivars; and growers could subsequently expand fig crops across Brazilian regions.

Regarding to seasons, canopy volume was higher in 2015/2016, but insufficient to affect production efficiency, there were therefore no differences between seasons (Figures 2C and 2D). The difference observed in canopy volume may be related to weather and climate conditions, where plants were exposed, such as temperature and precipitation. 


\section{Chemical characteristics}

There was a significant effect of the interaction between cultivars. For soluble solids, 'Troyano', 'White Genova' and 'Roxo de Valinhos' showed the highest averages, while 'PI-189' the lowest one (Table 1).

Table 1

Means values of soluble solids content (SS), pH, titratable acidity (TA), ratio (SS/TA), reducing sugars, non-reducing sugars and total sugars of four fig fruit cultivars

\begin{tabular}{|cccccccc|}
\hline Fig cultivars & SS ( ${ }^{\circ}$ Brix) & $\mathrm{pH}$ & $\begin{array}{c}\text { TA } \\
\text { (\% citric acid) }\end{array}$ & $\begin{array}{c}\text { SS/TA } \\
\text { Pl-189 }\end{array}$ & $\begin{array}{c}\text { Reducing } \\
\text { sugars (\%) }\end{array}$ & $\begin{array}{c}\text { Non-reducing } \\
\text { sugars (\%) }\end{array}$ & $\begin{array}{c}\text { Total } \\
\text { sugars (\%) }\end{array}$ \\
\hline Roxo de Valinhos & $9.53 \mathrm{a}$ & $4.87 \mathrm{~d}$ & $0.24 \mathrm{a}$ & $24.49 \mathrm{~b}$ & $2.91 \mathrm{~b}$ & $0.63 \mathrm{a}$ & $3.58 \mathrm{c}$ \\
\hline Troyano & $11.50 \mathrm{a}$ & $4.78 \mathrm{~b}$ & $0.18 \mathrm{~b}$ & $53.76 \mathrm{a}$ & $6.76 \mathrm{a}$ & $0.67 \mathrm{a}$ & $7.47 \mathrm{~b}$ \\
\hline White Genova & $10.90 \mathrm{a}$ & $5.13 \mathrm{a}$ & $0.18 \mathrm{~b}$ & $61.94 \mathrm{a}$ & $7.79 \mathrm{a}$ & $1.85 \mathrm{a}$ & $9.73 \mathrm{a}$ \\
\hline Means & 9.45 & 4.49 & 0.21 & 47.95 & 6.31 & 1.07 & 7.23 \\
\hline CV (\%) & 12.51 & 1.89 & 11.03 & 21.57 & 13.20 & 32.61 & 11.87 \\
\hline LSD & 2.61 & 0.19 & 0.05 & 22.84 & 1.84 & 1.24 & 1.89 \\
\hline
\end{tabular}

Means followed by the same letter for cultivars does not differ among them by Tukey's test $(p<0.05)$.

Rodrigues et al. (2019b) found higher values of soluble solids contents for 'Roxo de Valinhos' (12.74 'Brix), 'White Genova' (11.51 'Brix), 'PI-189' (12.48 'Brix) and 'Troyano' (13.68 'Brix); according to them, the highest levels of soluble solids is associated with edaphic and climatic conditions of the growing regions, since high temperature leads to sweeter fig fruits.

The lowest value of $\mathrm{pH}$ (3.87) and the highest value of titratable acidity $(0.24$ $\mathrm{g}$ citric acid $100 \mathrm{~g}-1$ ) was found in 'PI-189' fruits, but there was no significant difference in these parameters from 'Troyano' (Table 1). This behaviour in $\mathrm{Pl}-189$ is because $\mathrm{pH}$ is the logarithmic value of the inverse of the hydrogen ion concentration $(\mathrm{H}+)$; $\mathrm{pH}$ therefore increases to reduce acidity at concentrations ranging between 2.5 and $0.5 \%$.
Regarding to titratable acidity, citric acid is the major organic acid found in fig pulps. Organic acids are formed within glycolytic pathway, where sugars are metabolized, as a result of the high acidity of fruits that is related to their low sugar contents (Adão \& Gloria, 2005), these findings were observed in 'PI-189' fruits, as they presented high titratable acidity and low soluble solids contents.

For soluble solids to titratable acidity ratio (SS/TA), 'PI-189' showed the lowest average, mainly because of the higher acidity found in this cultivar, while the others did not show any significant difference. The values of SS/TA ratio are easily changeable, as depends on several factors, such as harvesting, growing areas, climate conditions, soil types and management practices. Thus, the highest values of SS/TA ratio demonstrated the 
balance between sweet and acid flavours, which is a fair more relevant characteristic to be considered than the isolated values for titratable acidity and soluble solids.

Al cultivars presented higher values for reducing sugars (glucose + fructose) than non-reducing sugars (sucrose) (Table 1). These findings were like those reported by Palmeira et al. (2019), who observed higher values of glucose and fructose than sucrose in figs of the cultivar Pingo de Mel; they reported

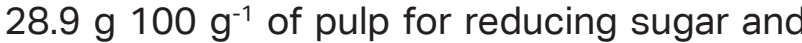

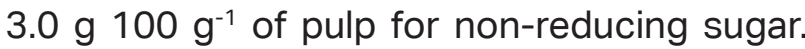
During ripening, there is a decrease in starch contents; and consequently, an increase in soluble sugars, especially sucrose, glucose, and fructose (Adão \& Glória, 2005). Still all fruits must be harvested at the same harvesting point.

For reducing sugar contents, 'PI-189' fruits showed the lowest average, while 'Roxo de Valinhos', 'Troyano' and 'White' Genova' had the highest ones. Therefore, 'PI-189' had low total sugar content (Table 1); consequently, low soluble solids content (Table 1). Furthermore, high sugar contents do not only confer sweetness to fruit, but also extend their shelf life, since sugars are the main product of the glycolytic metabolic pathway, whose is also responsible for cellular respiration to produce energy in the form of ATP (Adão \& Gloria, 2005).

\section{Bioactive compounds}

Regardless cultivars, results detected the same amount of ascorbic acid in fruits (Table 2), with the average of $29.47 \mathrm{mg} 100$ $\mathrm{g}^{-1}$. Moreover, the amount of ascorbic acid was $10.0 \mathrm{mg} 100 \mathrm{~g}^{-1}$ in cultivar Brown Turkey, according to Pande and Akoh (2010). Ascorbic and dehydroascorbic acids have been used as quality indicators, since they present vitamin activity as vitamin $\mathrm{C}$; however, the amount of ascorbic acid in fruits depends on genetic material, growing conditions, harvesting point and storage (Arvaniti et al., 2019). Besides that, ascorbic acid is also classified as antioxidants.

For the other bioactive compounds, a few differences were detected in the cultivars with regards to anthocyanin and carotenoids, but the cultivars did not differ from one to another for phenolic compounds, flavonoids and chlorophylls (Table 2).

Therefore, the averages of total phenolic compounds and total flavonoids

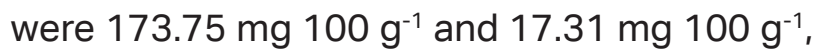
respectively (Table 2 ). In a study with some fig cultivars harvested at different times, Veberic et al. (2008) reported averages values from 5 to $35 \mathrm{mg} 100 \mathrm{~g}^{-1}$ for phenolic compounds, which was unlikely this present study. The phenolic compounds are found in fruits and vegetables and they have high antioxidant potential. However, the content of phenolic compounds in fruits and vegetables varies according to the species, cultivars, ripening stage and growth conditions (Reynerston, Yang, Jiang, Basile, \& Kennelly, 2008; Soethe, Steffens, Amarante, Martin, \& Bortolini, 2016).

Moreover, the contents of bioactive compounds may even vary depending on which part of the fruit. By assessing $18 \mathrm{fig}$ types in Spain, Vallejo et al. (2012) reported that phenolic compounds were mainly concentrated in peel (19.1 to $140.2 \mathrm{mg} 100$ $\mathrm{g}^{-1}$ ) and then in pulp (0 to $\left.11.3 \mathrm{mg} 100 \mathrm{~g}^{-1}\right)$. By evaluating the bioactive compounds in cultivar Pingo de Mel, Palmeira etal. (2019) also reported higher phenolic contents in peel $(152.0 \mathrm{mg}$ $\left.100 \mathrm{~g}^{-1}\right)$ and then in pulp (54.2 $\mathrm{mg}^{100 \mathrm{~g}^{-1}}$ ). 
Nevertheless, the fruits were frozen in liquid nitrogen and macerated without peeling and pulping in the present study, since consumers commonly eat the pulp of fig and discarded the peel. The composition of phenolic compounds results from the partial oxidation or partial sugars and chemicals through glycolysis and tricarboxylic acid cycle (Soethe, et al., 2016). However, the differences in sugar content and titratable acidity did not reflect differences in total phenolic compounds.

Table 2

Means values of Ascorbic acid (AA), total phenolics compounds (PHE), total flavonoids (FLA), total chlorophyll (CHL), total anthocyanins (ANT), total carotenoids (CAR) and antioxidant activity (ANTX) of four fig fruit cultivars

\begin{tabular}{|c|c|c|c|c|c|c|c|}
\hline Fig cultivars & $\begin{array}{c}\text { AA } \\
\left(\mathrm{mg} 100^{-1}\right) \\
\left.\mathrm{g}^{-1}\right)\end{array}$ & $\begin{array}{c}\text { PHE } \\
\left(\mathrm{mg} 100^{-1}\right) \\
\left.\mathrm{g}^{-1}\right)\end{array}$ & $\begin{array}{c}\text { FLA } \\
(\mathrm{mg} 100 \\
\left.\mathrm{g}^{-1}\right)\end{array}$ & $\begin{array}{c}\mathrm{CHL} \\
(\mu \mathrm{g} 100 \\
\left.\mathrm{g}^{-1}\right)\end{array}$ & $\begin{array}{c}\text { ANT } \\
(\mu g \text { 100 } \\
\left.g^{-1}\right)\end{array}$ & $\begin{array}{c}\text { CAR } \\
(\mu g 100 \\
\left.g^{-1}\right)\end{array}$ & $\begin{array}{c}\text { ANTX } \\
\text { (mg } 100 \\
g^{-1} \text { TEAC) }\end{array}$ \\
\hline PI-189 & $25.47 a$ & $176.62 \mathrm{a}$ & 20.37 a & $189.93 a$ & $392.74 a$ & $131.39 a$ & $23.01 \mathrm{a}$ \\
\hline Roxo de Valinhos & $31.10 a$ & $199.31 \mathrm{a}$ & $16.05 a$ & $110.18 a$ & $231.79 a b$ & $95.13 b$ & $26.66 \mathrm{a}$ \\
\hline Troyano & $30.81 \mathrm{a}$ & $152.29 \mathrm{a}$ & $18.71 \mathrm{a}$ & $132.91 \mathrm{a}$ & $127.61 \mathrm{~b}$ & $137.14 \mathrm{a}$ & $8.54 b$ \\
\hline White Genova & $30.51 \mathrm{a}$ & $166.77 \mathrm{a}$ & $14.12 \mathrm{a}$ & $108.87 a$ & $185.14 b$ & $84.79 b$ & $16.44 a b$ \\
\hline Means & 29.47 & 173.75 & 17.31 & 135.47 & 234.32 & 112.11 & 18.66 \\
\hline CV (\%) & 25.15 & 13.63 & 20.98 & 49.51 & 38.99 & 11.73 & 32.13 \\
\hline LSD & 16.37 & 52.31 & 8.02 & 148.12 & 201.77 & 29.05 & 13.24 \\
\hline
\end{tabular}

Means followed by the same letter for cultivars does not differ among them by Tukey's test $(p<0.05)$.

The ultraviolet radiation significantly affects plant cells, especially UV-B; thus, radiation increases in phenolic contents (Meyers, Watkins, Pritts, \& Liu, 2003); explaining why all fruits showed high values of polyphenols and flavonoids at high temperatures, as it is associated to radiation exposures.

The high predominance of anthocyanin and carotenoids in detriment of total chlorophyll (Table 2) was detected. If figs were harvested when they were ripe, they presented lower levels of chlorophyll levels than the other pigments, since chlorophyll might already undergo degradation, or was converted into other pigments at harvesting point. Furthermore, there were no differences for chlorophyll levels at all, but there were significant differences related to anthocyanin and carotenoids levels (Table 2 ).

Fruits of 'PI-189' and 'Roxo de Valinhos' showed the highest values of anthocyanin, but the values of 'Roxo de Valinhos' did not differ from all cultivars (Table 2). Anthocyanin is classified as a flavonoid; besides it is responsible for the red, pink, purple and blue colour of the plants; explaining the intense purple peel colour of these cultivars, in addition to intense pink pulp colour of 'PI-189'.

Figs are rich in anthocyanins in the peel, followed by the flesh. Dueñas, Alonso, Buelga and Bailón (2008) reported that most 
of anthocyanin are found in peel (32-97 $\left.\mu \mathrm{g} \mathrm{g}^{-1}\right)$, whereas dark pulp varieties contains about 14 $\mu \mathrm{g} \mathrm{g}^{-1}$, while light pulp approximately $1.5 \mu \mathrm{g} \mathrm{g}^{-1}$. The cultivar Bursa is commonly grown in Spain and presents similar values, that is, $41 \mu^{-1} \mathrm{~g}^{-1}$ in peel and $1 \mu \mathrm{g} \mathrm{g}^{-1}$ in pulp (Solomon et al., 2006).

For carotenoid contents, the highest averages were found in 'Troyano' $(137.14 \mu \mathrm{g}$ $\left.100 \mathrm{~g}^{-1}\right)$ and 'PI-189' (131.39 $\left.\mu \mathrm{g} 100 \mathrm{~g}^{-1}\right)$ (Table 2). The ripe fruits of 'Troyano' are somewhat yellow, in other words, carotenoids pigments are responsible for the yellow, orange and red colour in plants. On the contrary, 'PI-189' fruits presented high carotenoid content, but the value of anthocyanin was even higher, as a result of purple peel and pink pulp.

The lowest pigmentation was observed in 'White Genova' fruits due to the low levels of anthocyanin and carotenoids (Table 2); consequently, affecting fresh fruit market, since consumers are more attracted to intense colour fruits. Therefore, consumers would often choose to buy 'Roxo de Valinhos' fruits that presents a great size and purple peel.

Several environmental factors such as light, low temperatures and stress conditions can activate the genes involved in anthocyanin and carotenoids biosynthesis (Chalker-Scott, 1999). The discrepancies observed in the bioactive compounds content of fruits and vegetables in literature are mainly related to analytical methods, ripening stages and growing system.

'Roxo de Valinhos', 'PI-189' and 'White Genova' presented highermeans for antioxidant activity, while the lowest one was found in 'Troyano' (Table 2). Some studies have already presented positive correlations between total phenolic contents and antioxidant activity in fresh figs (Solomon et al., 2006; Veberic et al.,
2008). However, there was no difference in this present study for phenolic compounds with regards to cultivars, except for anthocyanin and carotenoids.

Anthocyanin presents a hydrophilic antioxidant activity, while carotenoids shows a lipophilic activity. Some studies reported that the DPPH method exhibited a greater affinity to hydrophilic compounds (Muller, Fröhlich, \& Böhm, 2011; Xu, Zhang, Cao, \& Lu, 2010; Thaipong, Boonprakob, Crosby, CisnerosZevallos, \& Byrne, 2006), explaining therefore the lowvalues of antioxidant activity in 'Troyano', but a high content of total carotenoid; besides that, evidencing the highest antioxidant activity found in 'Roxo de Valinhos' and 'PI-189'. Anthocyanins is a potent antioxidant, since acts by donating hydrogen atom due to the number of hydroxyl groups, the catechol moiety in the $\mathrm{B}$ ring and positive charged oxonium ion in the $\mathrm{C}$ ring (Pojer, Mattivi, Johnson, \& Stockley, 2013).

\section{Principal component analysis}

The PCA of fig cultivars explained $62 \%$ of the data variation with the first two components (PC1 + PC2) (Figure 3).

Regarding scores, cultivars were clearly separated, especially 'PI-189' and 'White' Genova. A PC1 separated 'PI-189' on the opposite side from 'Troyano' and 'White Genova', showing a difference between the first and the last two. Based on the PC1, 'Roxo de Valinhos' is in the intermediate region, but did not significantly differ from them, as observed by the 'White Genova' scores. The separation observed in PC1 occurred as follows, the scores on the left side are positively correlated with 'PI-189' for production efficiency and anthocyanins; besides that, the scores on the 
right side are positively correlated with 'White Genova' for ascorbic acid, SS/TA ratio and sugar, while 'Troyano' for total sugars, soluble solids, $\mathrm{pH}$ and canopy volume (Figures $3 \mathrm{~A}$ and 3B).
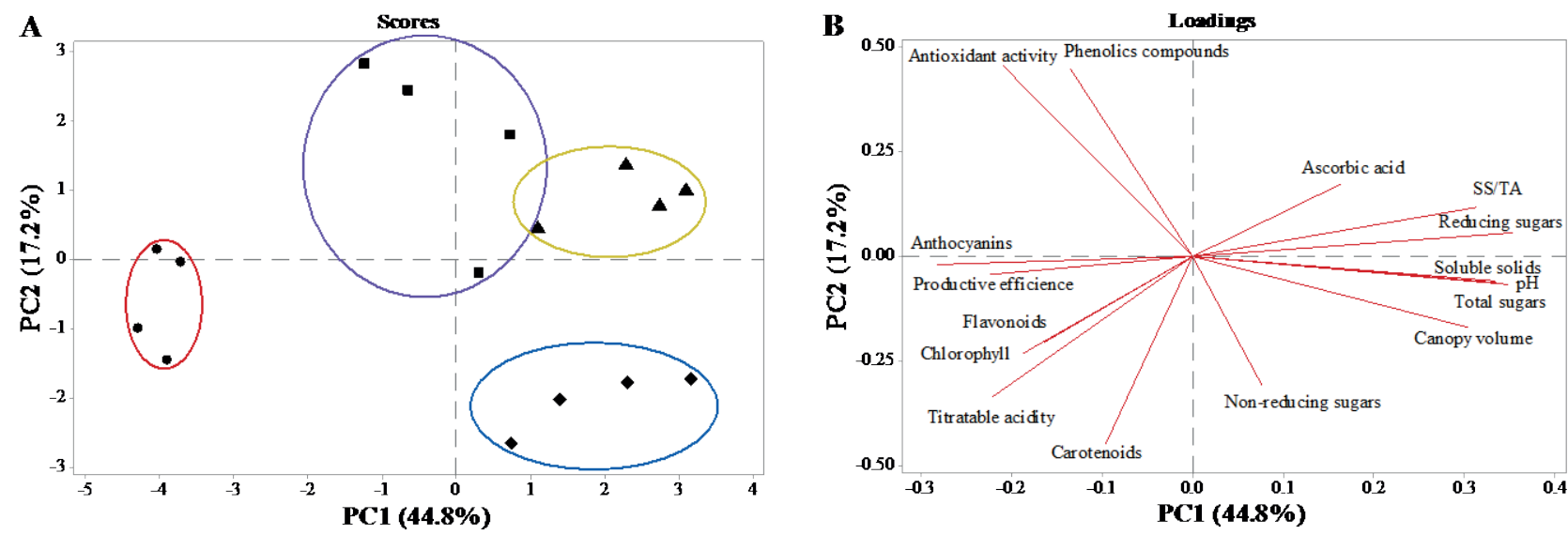

Figure 3. Principal component analysis of the canopy volume, productive efficiency, chemical and biochemical results of fig fruit cultivars PI-189 (๑), Roxo de Valinhos ( $\mathbf{\square})$, Troyano ( $\downarrow$ ) and White Genova (A). The observed loadings (A) and the variables loadings on PC1 and PC2 (B).

One must carefully consider the strong positive correlation of 'PI-189' with productive efficiency, since its scores are in the opposite quadrant to the canopy volume, that is, the greater production efficiency can be explained under the lower canopy volume. But the high productive efficiency of 'Roxo de Valinhos' (Figure $2 \mathrm{~B}$ ) is due to the higher production, since it is in an intermediate position between productive efficiency and canopy volume (Figure $3 \mathrm{~A}$ and $3 \mathrm{~B}$ ).

By analyzing the PC2, it appears that the cultivar separation was less pronounced, so that only 'Troyano' and 'White Genova' had all the scores on totally opposite sides. Even so, the main variables responsible for the separation in PC2 were phenolic compounds and antioxidant activity (correlated with 'Roxo de Valinhos'); non-reducing sugars (correlated with 'Troyano'); flavonoids, chlorophyll and titratable acidity (correlated with 'PI-189'); and carotenoids (intermediate region between 'P1189' and 'Troyano') (Figure 3A and 3B).

In figs, the strong influence of phenolic compounds on antioxidant activity in comparison to carotenoids was already mentioned (Figure $3 \mathrm{~B}$ ). In a study with several fig cultivars, Vallejo et al. (2012) observed in fruits the presence of chlorogenic acid, flavones (luteolin, kaempferol and rutinoside), flavonoids (quercetin acetylglucoside, quercetin rutinoside and quercetin glucoside), and anthocyanins (cyanidin glucoside and cyanidin rutinoside); according to them, the highest compound concentration in fig peels are anthocyanins.

Through PCA, the evaluation of fig cultivars presented characteristics that are striking enough to differentiate them. According to Mawa, Husain and Jantan (2013), 
the genetic variability in figs decreased with the disappearance of harvested species in the past, associated with reduction of agricultural areas across the world. Thus, selection and characterization of these materials is crucial for preserving the variability in fig cultivars.

\section{Conclusions}

The fig cultivars presented remarkable characteristics that can differentiate them. The cvs. Roxo de Valinhos, PI-189 and Troyano presented the highest production efficiency, indicating the possible varietal diversification for fig growers. Also the fig cultivars have a high level of antioxidants and can be highly accepted by consumers.

\section{Acknowledgments}

This work was supported by the National Council for Scientific and Technological Development (CNPq process 304455/2017-2).

\section{References}

Adão, R. C., \& Glória, M. B. A. (2005). Bioactive amines and carbohydrate changes during ripening of 'Prata' banana (Musa acuminata x Musa balbisiana). Food Chemistry, 90(4), 705-711. doi: 10.1016/j. foodchem.2004.05.020

Arvaniti, O. S., Samaras, Y., Gatidou, G., Thomaidis, N. S., \& Stasinakis, A. S. (2019). Review on fresh and dried figs: chemical analysis and occurrence of phytochemical compounds, antioxidant capacity and health effects. Food Research International, 119(2019), 244-267. doi: 10. 1016/j.foodres.2019.01.055
Association of Official Analytical Chemists (1995). Official methods of analysis. Method $n^{\circ}$. 967.21. Washington: AOAC.

Brand-Willians, W., Cuvelier, M. E., \& Berset, C. (1995). Use of a free radical method to evaluate antioxidant activity. LWT - Food Science and Technology, 28(1), 25-30. doi: 10.1016/S0023-6438(95) 80008-5

Cantuaria-Avilés, T., Mourão, F. A. A., Fo., Stuchi, E. S., Silva, S. R., \& Nunez, E. (2010). Tree performance and fruit yield and quality of 'Oktisu' Satsuma mandarin grafted on 12 rooststocks. Scientia Horticulturae, 123(3), 318-322. doi: 10.1016/j.scienta. 2009.09.020

Chalker-Scott, L. (1999). Environmental significance of anthocyanin in plant stress responses. Photochemistry and Photobiology, 70(1), 1-9. doi: 10.1111/ j.1751-1097.1999.tb01944.x

Corrêa, R. C., Peralta, R. M., Haminiuk, C. W., Maciel,G.M.,Bracht,A.,\&Ferreira,I.C.(2018). New phytochemicals as potential human anti-aging compounds: Reality, promise, and challenges. Critical Reviews in Food Science and Nutrition, 58(6), 942-957. doi: 10.1080/10408398.2016.1233860

Crisosto, C. H., Bremer, V., Ferguson, L., \& Crisosto, G. M. (2010). Evaluating quality atributes of four fresh fig (Ficus carica L.) cultivars harvested at two maturity stages. HortScience, 45(4), 707-710. doi: 10.21273/HORTSCI.45.4.707

Cunha, A. R., \& Martins, D. (2009). Classificação climática para os municípios de Botucatu e São Manuel-SP. Irriga, 14(1), 1-11. doi: 10.15809/irriga.2009v14n1p1-11

Dueñas, M., Alonso, J. J. P., Buelga, C. S., \& Bailón, T. E. (2008). Anthocyanin composition in fig (Ficus carica L.). Journal 
of Food Composition and Analysis, 21(2), 107-115. doi: 10.1016/j.jfca.2007.09.002

Food and Agriculture Organization (2020). World production of fig, 2018. Retrieved from http://www.fao. org/faostat/en/\#data/ QC

Instituto Adolfo Lutz (2005). Métodos físicoquímicos para análise de alimentos (4a ed.). São Paulo, SP: IAL.

Khadivi, A., Anjam, R., \& Anjam, K. (2018). Morphological and pomological characterization of edible fig (Ficus carica L.) to select the superior trees. Scientia Horticulturae, 238(19), 66-74. doi: 10.1016/j. scienta.2018.04.031

Mawa, S., Husain, K., \& Jantan, I. (2013). Ficus carica L. (Moraceae): phytochemistry, traditional uses and biological activities. Evidence-Based Complementary and Alternative Medicine, 2013, 1-8. doi: 10.11 55/2013/974256

Mendel, K. (1956). Rootstock-scion relationships in Shamouti trees on light soil. Ktavim, 6, 35-60.

Meyers, K. J., Watkins, C. B., Pritts, M. P., \& Liu, R. H. (2003). Antioxidant and antiproliferative activities of strawberries. Journal of Agricultural and Food Chemistry, 51(23), 6887-6892. doi: 10.1021/jf0345 06n

Muller, L., Fröhlich, K., \& Böhm, V. (2011). Comparative antioxidant activities of carotenoids measured by ferric reducing antioxidant power (FRAP), ABTS bleaching assay ( $\alpha$ TEAC), DPPH assay and peroxyl radical scavenging assay. Food Chemistry, 129(1), 139-148. doi: 10.1016/j.foodchem.2011.04.045

Nelson, N. (1944). A photometric adaptation of somogyi method for determination of glucose. Journal of Biological Chemistry, 153(2),375-380.doi:Retrievedfromhttps:// pdfs.semanticscholar.org/131b/e395 d4d24726d051472489140cd543aa839e

Palmeira, L., Pereira, C., Dias, M. I., Abreu, R. M. V., Corrêa, R. C. G., Pires, T. C. S. P.,... Ferreira, I. C. F. R. (2019). Nutritional, chemical and bioactive profiles of different parts of a Portuguese common fig (Ficus carica L.) variety. Food Research International, 126(2019), 1-10. doi: 10.1016/j.foodres. 2019. 108572

Pande, G., \& Akoh, C. C. (2010). Organic acids, antioxidant capacity, phenolic content and lipid characterisation of Georgia-grown underutilized fruit crops. Food Chemistry, 120(4), 1067-1075. doi: 10.1016/j.food chem.2009.11.054

Pojer, E., Mattivi, F., Johnson, D., \& Stockley, C. (2013). The case for anthocyanin consumption to 521 promote human health: a review. Comprehensive Reviews in Food Science and Food Safety, 12(2013), 522 483-508. doi: 10.1111/1541-4337. 12024

Popova, M., Bankova, V., Butovska, D., Petkov, V., Nikolova-Danyanova, B., Sabatini, A. G.,... Bogdanov, S. (2004). Validated methods for the quantification of biologically active constituents of poplar-type propolis. Phytochemical Analysis, 15(4), 235-240. doi: 10.1002/pca.777

Reynerston, K.A., Yang, H., Jiang, B.,Basile,M.J.,\& Kennelly, E. J. (2008). Quantitative analysis of antiradical phenolic constituents from fourteen edible Myrtaceae fruits. Food Chemistry, 109(4), 883-890. doi: 10.1016/j. foodchem.2008.01.021

Rodrigues, M. G. F., Correa, L. S., \& Boliani, A. C. (2009). Avaliação de seleções mutantes 
de figueira cv Roxo de Valinhos. Revista Brasileira de Fruticultura, 31(3), 771777. doi: 10.1590/S0100-2945200900 0300021

Rodrigues, M. G. F., Ferreira, A. F. A., Monteiro, L. N. H., Santos, T. P., Lisboa, L. A. M., \& Figueiredo, P. A. M. (2019a). Initial growth and physiological indexes of Fig accessions in active germiplasm bank. Revista Brasileira de Fruticultura, 41(4), e-154. doi: 10.1590/0100-29542019154.

Rodrigues, M. G. F., Monteiro, L. N. H., Ferreira, A. F. A., Santos, T. P., Pavan, B. E., Neves, V. A. B., \& Boliani, A. C. (2019b). Biometric characteristics among fig tree genotypes in Brazil. Genetics and Molecular Research, 18(2), e-18191. doi: 10.4238/gmr18191.

Sims, D. A., \& Gamon, J. A. (2002). Relationships between leaf pigment content and spectral reflectance across a wide range of species, leaf structures and developmental stages. Remote Zensing of Environment, 81(2-3), 337-354. doi: 10.1016/S0034-4257(02)00010-X

Soethe, C., Steffens, C. A., Amarante, C. V. T., Martin, M. S. de, \& Bortolini, A. J. (2016). Quality, phenolic compounds, and antioxidant activity of 'Tupy' and 'Guarani' blackberries stored at different temperatures. Pesquisa Agropecuária Brasileira, 51(80), 950-957. doi: 10.1590/ S0100-204X20160008 00007

Solomon, A., Golubowicz, S., Yablowicz, Z., Grossman, S., Bergman, M., Gottlieb, H.,... Flaishman, M. A. (2006). Antioxidant activities and anthocyanin content of fresh fruits of common fig (Ficus carica L.). Journal of Agricultural and Food Chemistry, 54(20), 7717-7723. doi: 10. 1021/jf060497h
Swain, T., \& Hills, W. E. (1959). The phenolic constituents of Prunus persica domestic: the quantitative analysis of phenolic constituents. Journal of the Science of Food and Agriculture, 10(2), 63-68. doi: 10. 1002/jsfa.2740100110

Thaipong, K., Boonprakob, U., Crosby, K., Cisneros-Zevallos, L., \& Byrne, D. H. (2006). Comparison of ABTS, DPPH, FRAP, and ORAC assays for estimating antioxidant activity from guava fruit extracts. Journal of Food Composition and Analysis, 19(6-7), 669-675. doi: 10.1016/j.jfca.2006.01.003

Vallejo, F., Marín, J. G., \& Tomás-Barberán, F. A. (2012). Phenolic compound content of fresh and dried figs (Ficus carica L.). Food Chemistry, 130(3), 485-492. doi: 10.1016/j. foodchem.2011.07.032

Veberic, R., Colaric, M., \& Stampar, F. (2008). Phenolic acids and flavonoids of fig fruit (Ficus carica L.) in the northern Mediterranean region. Food Chemistry, 106(1), 153-157. doi: 10.1016/j.foodchem. 2007. 05.061

Xu, C., Zhang, Y., Cao, L., \& Lu, J. (2010). Phenolic compounds and antioxidant properties of different grape cultivars grown in China. Food Chemistry, 119(4), 1557-1565. doi: 10.1016/j.foodchem.2009.09. 042 
